\title{
Powdery mildew on greengage (Prunus domestica subsp. italica var. claudiana) detected in Iran
}

\author{
Mahdi Arzanlou ${ }^{1} \cdot$ Mohsen Torbati $^{1}$ \\ Received: 15 August 2016 / Accepted: 19 January 2017 / Published online: 27 January 2017 \\ (C) Australasian Plant Pathology Society Inc. 2017
}

\begin{abstract}
In November 2015, white, powdery colonies were found on leaves of greengage (Prunus domestica subsp. italica var. claudiana) in the Meshginshahr (Ardabil province) and Khoy (West Azarbaijan province) regions of Iran. The circular colonies with chasmothecia scattered throughout were present mainly on the upper surface of the leaves. The fungus associated with the white colonies was identified as Podosphaera tridactyla using morphological and molecular characteristics. This paper details the first record of a powdery mildew on greengage in Iran.
\end{abstract}

\section{Keywords Podosphaera tridactyla $\cdot$ Chasmothecia}

Greengage (Prunus domestica subsp. italica var. claudiana) is a type of plum that is widely grown in Iran. During a field excursion in November 2015, powdery fungal colonies were observed on leaves of greengage trees in the Meshginshahr region (Ardabil province) and the Khoy region (West Azerbaijan province) of Iran. The disease symptoms were observed periodically at 3-4 day intervals. Infected leaves were placed and stored in paper bags before further examination. Fungal masses along with chasmothecia were mounted in distilled water and examined microscopically using the smash mount technique described by Arzanlou et al. (2007). Twenty measurements were made for each microscopic struc-

Mahdi Arzanlou

Arzanlou@ tabrizu.ac.ir

1 Plant Protection Department, Faculty of Agriculture, University of Tabriz, P.O. Box 5166614766, Tabriz, Iran ture using a light Olympus-BX41 microscope with a 40× objective lens and $95 \%$ confidence intervals were calculated for each parameter. Photographs were captured using an Olympus digital camera system (DP 25, Olympus, Tokyo, Japan) mounted on microscope and software to analyze photographs.

Symptoms and signs of the disease initially appeared as circular, white colonies mainly on the upper surface of young, expanding leaves and as the leaves developed the colonies increased in size, the leaf tissue beneath the colonies became chlorotic and later necrotic, and chasmothecia appeared in the colonies. Chasmothecia were scattered, turning from brown when immature to black when mature (Fig. 1). Mature chasmothecia were globose with a diameter of (80-) 84-86 (-90) $\mu \mathrm{m}$, with 2-4 appendages on the upper part of the chasmothecia, each (280-) 292-304 (-330) $\mu \mathrm{m}$ long and dichotomously branched 3-5 times at the distal end. Each chasmothecium contained a single sessile ascus, (60-) 77$84(-92) \times(60-)$ 67-71 (-75) $\mu \mathrm{m}$ diam (Fig. 2), in which there were 4-8 ellipsoid-subglobose, hyaline ascospores, $18-35 \times 11-21 \mu \mathrm{m}$. The asexual state of fungus was not observed. The fungus had morphological features identical to those described for P. tridactyla (Braun and Cook 2012).

To further confirm the identity of species, the rDNA internal transcribed spacer region (ITS1-5.8S-ITS2) was amplified and sequenced using ITS1 and ITS4 (White et al. 1990). For DNA extraction a small piece of mycelia was picked up from the surface of leaf using a sterile toothpick and suspended in $50 \mu \mathrm{l}$ TE buffer in PCR tubes, then mashed with a sterile pipette tip. The samples were placed in thermocycler at $95{ }^{\circ} \mathrm{C}$ for $5 \mathrm{~min}$. DNA extracts were stored at $-20{ }^{\circ} \mathrm{C}$ prior to use. The reaction mixture and cycling conditions were the same as described by Arzanlou et al. $(2012,2013)$. A BLAST search against the nucleotide 
Fig. 1 Symptomatic leaves of P. domestica subsp. italica var. claudiana infected by P. tridactyla
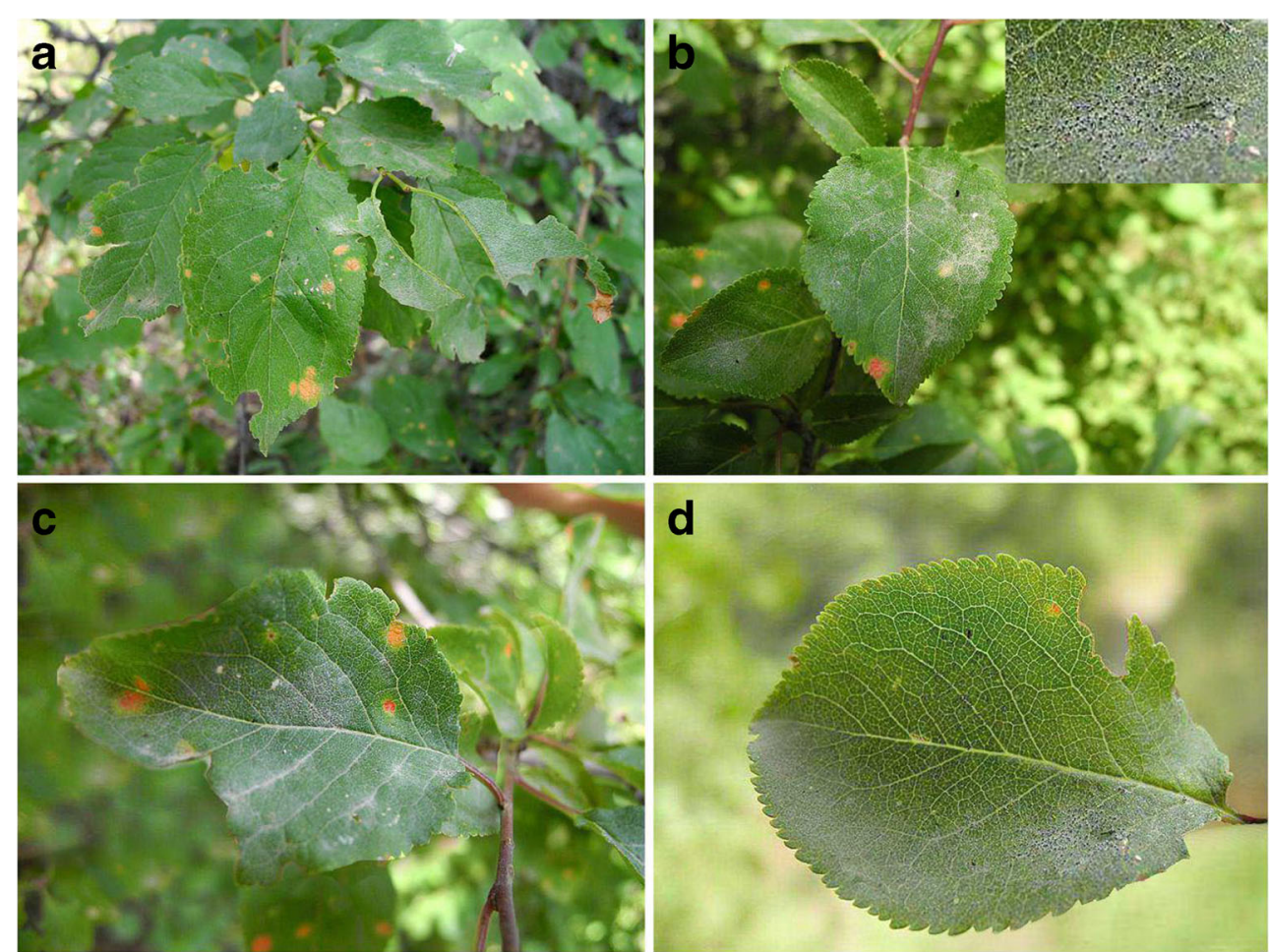

sequence data at GenBank showed 99-100\% similarity with Podosphaera tridactyla isolates from plant species in Prunus subgenera, available at GenBank (AY833658.1,
AY833657.1 and AY833656.1). The sequence obtained in this study is available in GenBank with the accession number KY110742. A dried specimen was deposited in the
Fig. 2 Podosphaera tridactyla a-c chasmothecia with appendages. d-e asci. Bars $(\mathbf{a}, \mathbf{d}-\mathbf{e})=20 \mu \mathrm{m},(\mathbf{b}-\mathbf{c})=50 \mu \mathrm{m}$
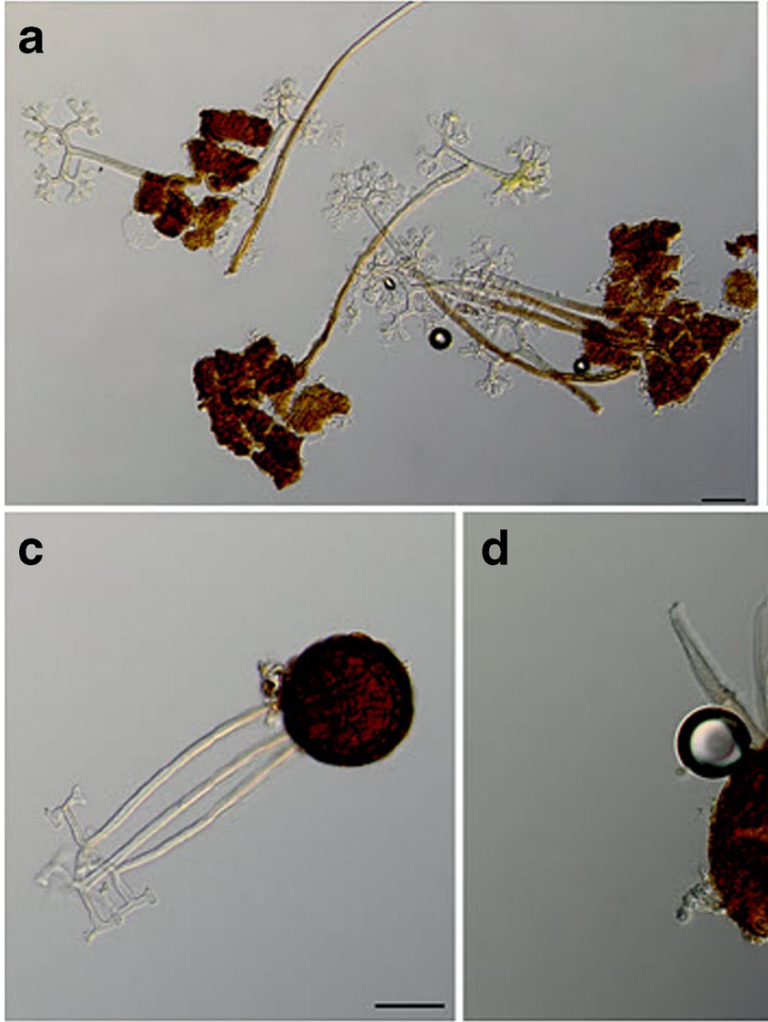

b

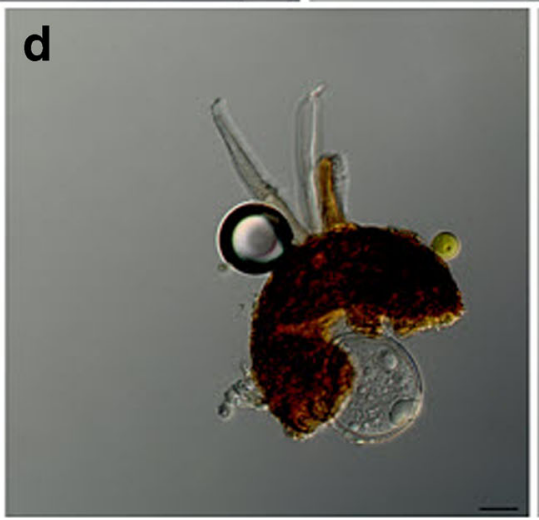

e

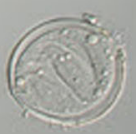


Fungal Herbarium of the Iranian Research Institute of Plant Protection (IRAN 16859 F).

Podosphaera tridactyla has been reported on sweet cherry (Prunus avium) in Europe, North America, South America, Australia, New Zealand, and Korea (Choi et al. 2015). Although this species has been previously reported on cherry plum ( $P$. divaricata) and common plum ( $P$. domestica) in Iran (Ershad 2009), to the best of our knowledge this is the first record of a powdery mildew on $P$. domestica subsp. italica var. claudiana in Iran. Little information exists on the biodiversity of powdery mildews in Iran. Recently, Khodaparast and Abbasi (2009) have provided a check list of species, host range and geographical distribution of powdery mildews in Iran based on previously published literature. However, most of the species have been identified and described using only morphological traits; such that, identification of the powdery mildew fungi in Iran in the light of recent molecular revisions is required (Braun and Cook 2012).

Acknowledgements We thank the Research Deputy of the University of Tabriz, for financial support of this research. The authors are indebted to Prof. Walter Gams for his valuable comments and critical reading of the manuscript.

\section{References}

Arzanlou M, Groenewald JZ, Gams W, Braun U, Shin H-D, Crous PW (2007) Phylogenetic and morphotaxonomic revision of Ramichloridium and allied genera. Stud Mycol 58:57-93

Arzanlou M, Torbati M, Jafary H (2012) Fruit rot of olive (Olea europaea) caused by Truncatella angustata. Plant Pathol Quar 2:117-123

Arzanlou M, Moshari S, Salari M, Badali H (2013) Molecular characterization and pathogenicity Phaeoacremonium spp. associated with esca disease of grapevine in northern Iran. Arch Phytopathol Plant Protect 46(4):375-388

Braun U, Cook RTA (2012) Taxonomic manual of the Erysiphales (powdery mildew). CBS Biodivers Ser 11: 1-707

Choi IY, Nam EY, Cho SE, Park JH, Shin HD (2015) First report of powdery mildew caused by Podosphaera tridactyla on sweet cherry in Korea. Plant Dis 99:1648

Ershad D (2009) Fungi of Iran, 3rd edn. Iranian Research Institute of Plant Protection, Tehran, $531 \mathrm{p}$

Khodaparast SA, Abbasi M (2009) Species, host range and geographical distribution of powdery mildew fungi (Ascomycota: Erysiphales) in Iran. Mycotaxon 108:213-216

White TJ, Bruns TD, Lee SB, Taylor JW (1990) Amplification and sequencing of fungal ribosomal RNA genes for phylogenetics. In: Innis N, Gelfand D, Sninsky J, White TC (eds) PCR protocols and applications - a laboratory manual. Academic Press, New York 